\title{
PLURALISME DAN DIALOG ANTAR UMAT BERAGAMA
}

\author{
Oleh: Irfan \\ ${ }^{1}$ Institut Agama Islam Muhammadiyah Sinjai, \\ Jl.Sultan Hasanuddin. No. 20 Balangnipa, Sinjai \\ $* * * *$
}

\begin{abstract}
Abstrak
Pluralisme agama merupakan fenomena yang tidak bisa dihindari adanya dan setiap agama muncul dalam lingkungan yang plural. Jika pluralisme agama tersebut tidak disikapi secara tepat maka akan menimbulkan problem dan konflik antar umat beragama, dan kenyataan ini telah terjadi pada agama-agama monotheis. Untuk mencari solusi konflik antar umat beragama perlu adanya pendekatan-pendekatan yang tepat. Bagaimanakah pendekatan-pendekatan yang digunakan dalam upaya melerai konflik antarumat beragama? Tulisan ini hendak mengungkap problem pluralisme agama dan dialog antar umat beragama beberapa pendekatan yang ditawarkan oleh para ahli. Pendekatan yang digunakan dalam melerai konflik antar umat beragama sebagaimana yang ditawarkan John Hick adalah pendekatan lintas agama (cross cultural), multikultural oleh Brian Fay, esoterisme oleh Schuon dan Hossein Nasr dengan philosophia perennis-nya.
\end{abstract}

\section{Kata Kunci: Pluralisme, Dialog, Antar Umat, Agama}

\section{PENDAHULUAN}

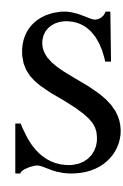

ecara historis, pada masa kolonial, masyarakat Muslim di kepulauan Nusantara merasa terancam dengan kebijakan politik kolonial yang memberi perlindungan terhadap kegiatan penyebaran agama Kristen. Akibatntya, hingga masa awal pasca kemerdekaan, kecurigaan Muslim terhadap Kristen dan Katolik dengan mudah terbentuk Namun demikian, keputusan para pendiri Republik Indonesia, yang sebagian besar juga terdiri dari para pemuka agama Islam, untuk menetapkan Pancasila sebagai dasar negara dapat ditunjuk sebagai upaya sungguh-sungguh dalam mencari sistem kenegaraan yang menjamin kerukunan dan pluralisme keagamaan.1

Menurut Abu Rabi’,2 meski Islam telah menjadi kekuatan nilai dalam menumbuhkan etos pluralisme keagamaan sejak Indonesia merdeka, potensi untuk menjadi gerakan sosial yang mundur ke belakang dengan sentimen anti-Kristennya tetap terbuka lebar. Berbagai kecenderungan dan pola pemikiran keislaman yang muncul akhir-akhir ini menggambarkan posisi Islam yang berbeda-beda dalam berhadapan dengan komunitas agama lain. Oleh sebab itu menurut Rabi', aspirasi politikkeagamaan yang berkembang akan tetap membuka peluang bagi tumbuhnya gerakan sosial Islam yang sulit menjunjung tinggi nilai-nilai toleransi, keterbukaan dan moderasi. Dan ini merupakan tantangan yang semakin nyata seiring dengan perkembangan wacana keagamaan pasca-modern.

1 Abu Rabi', "Christian-Muslim Relations in Indonesia: The Challenges of The Twenty-First Century" Jurnal Studia Islamika (Jakarta: IAIN Syarif Hidayatullah, 1998).

2 Ibid. 
Menurut Sudarto,3 pada masa kolonial, ketegangan dalam hubungan umat Islam dan umat Kristen lebih dipicu oleh kegiatan penginjilan (misionaris) yang mendapat bantuan besar dari pemerintahan penjajah Belanda, baik bantuan politik maupun finansial. Sementara pada masa Orde lama ketegangan antar dua komunitas umat beragama itu mencuat saat pembahasan UUD 1945 dan pada sidang Konstituante hasil Pemilu 1955. Dalam pembukaan UUD 1945 telah ditetapkan tujuh kata yang bernuansa islami, yang oleh kaum Kristen dianggap sebagai upaya pembentukan negara Islam, yang pada akhirnya dihapuskan.

Berangkat dari perkembangan situasi umat beragama yang tidak menguntungkan, maka pada 30 November 1967 diadakan "dialog dari atas" yang dipelopori oleh Pemerintah melalui Menteri Agama, KH. Muhammad Dahlan. Tetapi dialog yang melahirkan wadah "Musyawarah Antar Agama" itu belum dianggap berhasil menyelesaikan konflik antar agama. Sampai pada periode berikutnya dialog itu menemukan kembali momentum barunya pada masa Mukti Ali menjadi Menteri Agama yang mencoba merumuskan dialog dengan berpijak pada iktikad baik dan sikap saling percaya dari masingmasing komuitas agama. Dan karena itu, Mukti Ali menghidupkan kembali wadah Musyawarah Antar agama dengan melibatkan lebih banyak tokoh dan pemimpin agama.

Sebenarnya sejak awal Orde Baru hingga sekarang--baik atas prakarsa pemerintah maupun masyarakat beragama itu sendiri--dialog antar umat beragama telah dibangun, bahkan menjadi agenda nasional demi terciptanya stabilitas keamanan serta lancarnya pembangunan--meskipun kemudian ada pihak yang menilai tidak berhasil, karena tidak adanya kesepakatan bersama berkenaan dengan prinsip-prinsip penyebaran agama.4 Bahkan masa antara tahun 1972-1977 tercatat pemerintah telah menyelenggarakan dialog yang berlangsung di 21 kota.5

Pada dekade tahun 1980-an hingga saat ini prakarsa dialog dalam mewujudkan kerukunan antarumat beragama dan sosialisasi pemahaman pluralisme ini pun terus dilakukan, baik oleh para tokoh agama, intelektual muda maupun pemerintah sendiri, misalnya dialog yang diselenggarakan oleh International Conference on Religion and Peace (ICRP) yang diprakarsai oleh Johan Efendi dan kawan-kawan, dialog kelembagaan (Institutional Dialogue), yakni dialog antar delegasi berbagai organisasi agama yang melibatkan majelis-majelis agama yang diakui pemerintah, seperti Majelis Ulama Indonesia (MUI), Persatuan Gereja Indonesia (PGI), Konferensi Waligereja Indonesia (KWI), Parisada Hindu Darma dan Perwalian Umat Budha Indonesia (WALUBI) dan seterusnya; dialog berwacana transformatif yang sering dilakukan oleh kalangan intelektual atau LSM seperti interfidei, paramadina, LKiS, LP3M, MADIA dan lain-lain.

Tapi kenyataannya sampai sekarang, ketegangan dan kerusuhan yang disebabkan oleh sentimen keagamaan (Islam-Kristen) di beberapa daerah, seperti di Situbondo, Tasikmalaya, Ketapang, Kupang,

3 Sudarta, Konflik Islam-Kristen, Menguak Akar Masalah Hubungan Antar umat Beragama di Indonesia, (Semarang: Pustaka Rizki Putra, 1999), 79-80.

4 Sumarthana, "Menuju Dialog Antar Iman", Pengantar dalam Dialog : Kritik dan Identitas Agama, (Yogyakarta: Dian/ Interfedei, Seri Dian I/Tahun I, 1993), X-xi.

5 Jurnal Ulumul Qur'an, IV (1993), 4. 
Ambon, Poso, Maluku dan seterusnya yang mengakibatkan hancurnya tempat-tempat ibadah seperti masjid, mushalla, dan gereja semakin bertambah parah kondisinya. Padahal upaya Pemerintah RI. dalam menyelesaikan masalah konflik di Poso, yang melahirkan wadah yang bernama Perundingan Malino I dan ditindaklanjuti dengan Perundingan Malino II untuk penyelesaikan konflik Maluku terus digalang. Dengan perundingan Malino II ini diharapkan menghasilkan kemanfaatan yang berarti bagi terciptanya perdamaian dan kerukunan hidup antar umat beragama di Indonesia. Tetapi upaya inipun, sebagaimana yang kita saksikan bersama, belum juga mampu mengatasi dan mencegah timbulnya kembali konflik antar umat beragama. Fenomena di atas menunjukkan kesenjangan (gap) antara idealitas agama (das sollen) sebagai ajaran dan pesan-pesan suci Tuhan dengan realitas empirik yang terjadi dalam masyarakat (das sein).

Seperti telah diketahui, bahwa dalam rangka membina dan memlihara kerukunan antar umat beragama di Indonesia, pemerintah telah mencarikan jalan keluar melalui pelbagai cara dan upaya, antara lain dengan menyelenggarakan dialog antartokoh agama; memfungsikan pranata-pranata agama sebagai media penyalur gagasan dan ide. Salah satu pranata agama yang selama ini diandalkan dalam menyalurkan program pemerintah tersebut adalah tokoh-tokoh agama. Tokoh-tokoh agama ini mempunyai kedudukan dan pengaruh besar di tengah-tengah masyarakatnya, karena mereka mempunyai beberapa kelebihan yang dimiliki, baik dalam ilmu pengetahuan, jabatan, keturunan dan lain sebagainya. Tokoh agama juga merupakan pemimpin informal dalam masyarakatnya, dan secara umum mereka tidak diangkat oleh pemerintah tetapi ditunjuk atas kehendak dan persetujuan dari masyarakat setempat.

Penelitian tentang "hubungan antarumat beragama" di Indonesia telah banyak dilakukan, misalnya yang dilakukan oleh Qowa'id66 di Kalimantan Selatan. Penelitian ini bersifat deskriptifevaluatif, yang berusaha menggambarkan pelaksanaan program dialog antar umat beragama. Tujuan akhir dari pendekatan penelitian ini adalah, mengetahui keberhasilan dan ketidakberhasilan dari pelaksanaan kegiatan program dialog dimaksud. Data yang dihimpun meliputi: kelemahan dan kelebihan kegiatan serta faktor penyebabnya. Sumber datanya mencakup tokoh agama dan tokoh masyarakat baik yang pernah terlibat dialog maupun yang belum, pelaksana dialog dan pejabat pemerintah setempat.

Secara umum kegiatan dialog berjalan dengan baik, walaupun dijumpai beberapa kelemahan atau kekurangan di pelbagai tahapan dan aspek. Di antara kelemahannya adalah, masalah persiapan pelaksanaan dialog oleh panitia yang masih kurang, kurangnya wawasan nara sumber mengenai agama lain, minimnya waktu penyelenggaraan, kurangnya fasilitas, kegiatan dan metode yang kurang variatif (menjenuhkan), termasuk kuranya materi buku/ referensi yang aktual. Secara umum kekurangan atau kelemahan tersebut dilatarbelakangi oleh beberapa sebab, antara lain: problem SDM

6 Qowa'id, "Dialog Antarumat Beragama di Kalimantan Selatan”, Penamas, 39, XIV, (2000). 2003).

7 Siti Zulaikha. "Toleransi Awu-awu: Potret Dialog Antar Agama di Jawa Timur", Gerbang (2002- 
yang masih relatif rendah, biaya dan fasilitas yang masih minim. Keberhasilan dialog ini antara lain: mereka bisa saling mengenal, lebih mengetahui berbagai problem yang dihadapi, bersedia saling mendengarkan dan saling introspeksi, tenggang rasa (toleran) dan seterusnya.

Penelitian tentang "potret dialog antaragama di Jawa Timur" yang dilakukan oleh Siti Zulaikha7 bertujuan mengetahui seberapa jauh gagasan dialog antarumat beragama di Jawa Timur mampu mengatasi konflik sosial berbau SARA di lokal masing-masing kota di Jawa Timur. Materi penelitian meliputi: 1) cara pandang aktvis dialog antar agama terhadap agama; 2) membongkar cara pandang para aktivis dialog antar agama terhadap sumber-sumber konflik agama yang berkembang di masyarakat; 3) menggali sebanyak mungkin model dialog antar uamt beragama yang dikembangkan; 4) mengukur sejauhmana implikasi yang muncul sebagai akibat dari gerakan yang telah dilakukan.

Penelitian yang dilakukan oleh Ismatu Ropi8 mengenai "kesenjangan hubungan Kristen-Islam di Indonesia" berusaha mengetahui sikap Muslim terhadap Kristen di Indonesia modern. Penelitian ini juga ingin melihat hubungan Muslim-Kristen di Indonesia. Penelitian M. Yahya9 terkait dengan "pemahaman masyarakat awam (Muslim-Kristen) terhadap agama mereka di Kabupaten Malang" mengungkap respon masyarakat awam (Muslim dan Kristen) terhadap dialog antar umat beragama yang sudah berlangsung selama ini.

Penelitian tentang "peran tokoh agama dalam mewujudkan kerukunan hidup antarumat beragama” juga dilakukan oleh Abdul Ghaffar Mahfuz10 di Pangkal Pinang. Penelitian tersebut bertujuan untuk mengetahui peran dan hubungan sosial antar tokoh agama dalam rangka mewujudkan kerukunan hidup antarumat beragama di kecamatan Bukit Intan Kotamadya Pangkal Pinang. Disamping itu penelitian ini juga mengidentifikasi faktor-faktor yang turut mempengaruhi pola hubungan yang diciptakan oleh para tokoh agama tersebut, baik faktor personalnya maupun maupun faktor sosialnya; bentuk-bentuk pranata sosial keagamaan yang dikembangkan oleh para tokoh agama.

\section{PEMBAHASAN}

\section{A. Pluralisme Agama}

Salah satu hal yang mewarnai dunia dewasa ini adalah pluralisme keagamaan, demikian ungkap Coward11 Pluralisme merupakan sebuah fenomena yang tidak mungkin dihindari. Manusia hidup

8 Ismatu Ropi, Fragile Relation: Muslims and Christians in Modern Indonesia, (Jakarta: Logos, 2000).

9 M. Yahya, et.al., Respon Masyarakat Awam (Islam-Kristen) Terhadap Dialog Antarumat Beragama di Kabupaten Malang, (Laporan Hasil Penelitian Hibah Bersaing Depag RI. 2002).

10 Abdul Ghaffar Mahfuz, Tokoh Agama dalam Mewujudkan Kerukunan Antarumat Beragama (Palembang: IAIN Raden Fatah 1997).

11 Coward, Pluralisme dan Tantangan Agama-agama (Yogyakarta: Kanisius: 1989), 5.

12 Ibid, 167.

13 David Tracy, Plurality and Ambiguity, Hermeneutic, Religion, Hope (University of Chicago Press, 1987), 89-90. 
dalam pluralisme dan merupakan bagian dari pluralisme itu sendiri, baik secara pasif maupun aktif, tak terkecuali dalam hal keagamaan.

Pluralisme keagamaan merupakan tantangan khusus yang dihadapi agama-agama dunia dewasa ini. Dan seperti pengamatan Coward12, setiap agama muncul dalam lingkungan yang plural ditinjau dari sudut agama dan membentuk dirinya sebagai tanggapan terhadap pluralisme tersebut. Jika tidak dipahami secara benar dan arif oleh pemeluk agama, pluralisme agama akan menimbulkan dampak, tidak hanya berupa konflik antar umat beragama, tetapi juga konflik sosial dan disintegrasi bangsa.

Menurut Tracy13, diantara agama-agama yang ada di dunia ini memang tidak ada yang memiliki esensi tunggal, tidak ada muatan tunggal tentang pencerahan atau wahyu, tidak ada cara tunggal tentang emansipasi atau liberasi yang dibangun dalam semua pluralitas itu. Ada perbedaan penafsiran tentang Tuhan itu sendiri: God, Emptiness, Suchness, the One, Nature, the Many. Ada perbedaan pemahaman mengenai apa yang diwahyukan oleh Tuhan tentang Tuhan dan tentang diri kita dalam hubungan kita tentang harmoni dan disharmoni dengan Tuhan tersebut. Ada perbedaan penafsiran tentang cara apa yang harus kita ikuti untuk mengubah (pandangan kita) dari pemusatandiri secara fatal menuju pemusatan-kepada Tuhan secara bebas. Tetapi diskurus dan cara-cara agama seperti itu kadang-kadang bisa saling melengkapi, dan pada batas tertentu, melengkapi beberapa aspek yang belum maju dari yang lain, tetapi pada saat yang sama juga bisa saling mengganggu dan melenyapkan.

Menurut Hick14, bahwa pluralisme agama mengimplikasikan pengakuan terhadap fondasi bersama bagi seluruh varitas pencarian agama dan konvergensi agama-agama dunia. Bagi sebagian lainnya, pluralsime agama mengimplikasikan saling menghargai di antara berbagai pandangan dunia (wold-view) dan mengakui sepenuhnya perbedaan tersebut. Jika yang pertama menekankan kebebasan beragama individu, maka yang kedua menekankan pengakuan atas denominasi sebagai pemberi jawaban khas. Hick memang, sebagaimana kata Soroush15, adalah seorang teolog yang membela pluralisme dan inklusivisme sejajar dengan Kung, Smart dan Toynbee.

Tetapi, kenapa pula pemeluk agama monoteis justru inheren dengan intoleransi dan kekerasan? Menurut Rodney Stark16, claim pemeluk agama monoteisme yang partikularistk-subjektif --bahwa agama yang dipeluknya adalah satu-satunya yang benar, yang hanya percaya pada satu Tuhan, Yang Esa dan Sejati (One True God)-- banyak memicu konflik. Stark menyoroti subjektivisme para pemeluk agama monoteistik (baik Yahudi, Kristen maupun Islam) yang memandang rendah agama lain. Melalui penelitiannya, Stark berkesimpulan, bahwa berbedaan agama dalam seluruh masyarakat berakar pada relung-relung sosial, kelompok-kelompok orang yang saling berbagi preferensi

14 Zakiyuddin, Ambivelensi Agama, Konflik dan Nirkekerasan (Yogyakarta: Lesfi, 2002), 20.

15 Soroush, Menggugat Otoritas dan Tradisi Agama, terj. Abdullah Ali (Bandung: Mizan. 2003).

16 Stark, One True God: Resiko Sejarah Bertuhan Satu, terj. M. Sadat Ismail (Jakarta: Nizam, Yogyakarta: Qalam. 2003), 171-173. 
berkaiatan dengan intensitas keagamaan.17 Ketika beberapa agama partikularistik yang kuat saling mengancam antara satu dengan yang lain, maka konflik akan termaksimalisasikan, begitu pula tingkat intoleransi. 18

Menurut Stark, pluralisme agama memang merupakan keniscayaan dan pluralisme dalam orde sosial dapat menjadi stabil selama dalam organisasi-organisasi keagamaan tidak terdapat satu pun dari padanya yang terlalu kuat. Namun jika sebaliknya yang terjadi, maka sudah dapat dipastikan akan terjadi konflik yang intens.19 Stark sampai pada kesimpulan, bahwa konflik agama akan menjadi memuncak jika beberapa organisasi keagamaan yang kuat dan partikularistik hidup berdampingan.20

Huston Smith, dalam memberikan komentar karya Schuon mengenai hubungan antar agamaagama, mengatakan bahwa segala sesuatu memiliki persamaan dan sekaligus perbedaan, demikian juga dengan agama. Agama-agama yang hidup di dunia ini disebut "agama" karena masing-masing memiliki persamaan. Persamaan atau titik temu antara agama-agama tersebut berada pada level esoterisme, sedangkan pada level eksoterieme, agama-agama tampak berbeda. 21

Menurut Raimundo Panikkar, untuk memahami agama-agama orang lain secara komprehensif, kita harus memahami agamanya melalui bahasa aslinya. Kita tidak bisa mengabaikan perbedaanperbedaan yang ada dalam masing-masing agama untuk menarik kesimpulan bahwa "semua harus menjadi satu". Menurutnya, ada tiga macam sikap keagamaan manusia: eksklusif, inklusif dan paralel/ plural. Sikap ekslusif artinya, seseorang menganggap bahwa hanya agamanya saja yang benar, sementara yang lain salah; sikap inklusif artinya seseorang beranggapan, bahwa agamanya yang paling benar, tetapi agama lain juga mengandung kebenaran; sikap plural artinya, seseorang menganggap bahwa semua agama sama dan mengandung kebenaran masing-masing. 22

\section{B. Dialog Antarumat Beragama}

Guna mengakomodasi hubungan antara agama-agama pada level internasional, maka pada tahun 1958, di Tokyo, diadakan kongres internasional oleh The International Association for The History of Religion, dalam Konggres itu Friedrich Heiler dari Marburg menerangkan bahwa memberi penerangan tentang kesatuan semua agama merupakan salah satu dari tugas-tugas yang amat penting dari ilmu agama. Orang yang mengakui kesatuan agama, menurutnya, harus memegangnya dengan serius dengan toleransi dalam kata-kata dan perbuatan. Di sini Heiler melihat betapa dekatnya agamaagama itu satu sama lainnya; dengan membandingkan strukturnya, keyakinan dan amalan-amalannya, ia dibawa kepada suatu yang transenden yang melampaui semua namun tetap imanen dalam hati manusia. Oleh karena itu, studi ilmu perbandingan agama merupakan pencegah paling baik untuk

17 Ibid., 175.

18 Ibid., 183.

19 Ibid., 76.

20 Ibid., 181.

21 Schuon, The transcendent Unity of Religions. Wheston (Illinois: The Theosophical Publishing House, 1984), xii.

22 Pannikar, Dialog Intra Religius (Yogyakarta: Kanisius, 1994), 18. 
melawan eksklusivisme, karena ia mengajarkan cinta; di mana ada cinta tentu di situ ada kesatuan dalam jiwa.

Di akhir pidatonya, Heiler menganalogikan pentingnya ilmu perbandingan agama dengan apa yang dilakukan oleh Helmholtz, penemu kaca mata, yang telah membantu jutaan orang yang sakit mata. Hal demikian juga berlaku bagi studi ilmiah tentang agama, usahanya untuk mencari kebenaran membawa akibat-akibat yang penting bagi hubungan yang praktis antara agama satu dengan lainnya. 23

Dan tidak menutup kemungkinan, bahwa belum tampaknya hasil yang signifikan dari pendekatan dialog dalam menyelesaikan konflik antarumat beragama selama ini karena pendekatan yang dilakukan masih bersifat top down, belum menggunakan model dialog yang bersifat buttom up sehingga bisa dijadikan sebagai bahan perbandingan dan evaluasi penyelenggaraan dialog kerukunan di masa mendatang.

Dalam melakukan dialog dengan agama lain, apapun bentuknya, diperlukan adanya sikap saling terbuka, saling menghormati dan kesediaan untuk mendengarkan yang lain. Sikap-sikap ini diperlukan untuk mencari titik temu (kalimatun sawa') antara berbagai agama, karena masing-masing agama mempunyai karakteristik yang unik dan kompleks.

Dalam kasus dialog antara Islam dan Kristen, menurut Hassan Hanafi24 keduanya mempunyai dua "karakteristik ideal" (ideal types) yang kaya untuk dikomparasikan dan selanjutnya bisa mengantarakan kepada suatu common platform. Dialog perlu dilakukan dengan mengedepankan prinsip humanisme, karena antara Islam dan Kristen mempunyai pandangan yang kosmopolit mengenai manusia yang lebih memudahkan untuk melakukan komparasi antara dua dimensi: antropologis dan teologis. Tuhan dan manusia, menurut Hanafi, merupakan kata kunci bagi timbulnya persatuan dan perpecahan antara kultur modernitas dan kultur tradisional atau antara Kristen dan Muslim di Timur.

Ada beberapa alasan keraguan sementara orang-orang muslim menanggapi dialog agama ini. Gerakan dialog ini adalah murni inisiatif Kristen Barat dan orang-orang Islam merasa diri mereka sebagai tamu yang diundang, tidak memiliki agenda dan merasa hasil yang bisa dicapai dari dialog ini sedikit. Keyakinan mereka bahwa misi Kristen merupakan agenda tambahan atas kolonialisme yang sering dilakukan orang-orang Kristen menambah ketidakpercayaan terhadap agenda Kristen dan dialog tersebut ditakutkan oleh orang-orang muslim sebagai agenda tersembunyi dari agenda evangelism. Ketidakpercayaan ini ditambah dengan ketidakadilan global Barat, khususnya dalam konflik Israel-Palestina.

23 Mukti Ali, Ilmu Perbandingan Agama di Indonesia (Bandung: Mizan, 1998), 84-86.

24 Hassan Hanafi, Religious Dialogue \& Revolution, Essay on Judaism, Christianity \& Islam (Cairo: The Anglo Egyptian Bookshop, 1977). 
Hal penting yang perlu diperhatikan dalam dialog ini menurut Hans Kung25 adalah, bahwa setiap orang beragama harus membuktikan keimanannya masing-masing. Terlepas dari semua perbedaan yang ada menurut Kung, orang Kristen dan Islam harus bertanggung jawab terhadap Tuhan dan melayani masyarakat manusia dengan penuh penghormatan satu sama lain.

Seyyed Hossein Nasr26 menawarkan kajian agama dengan philosohia perennis, karena dia melihat bahwa banyaknya kajian keagamaan di Barat kurang memahami bahwa realitas agama sebagai agama dan bentuk-bentuk yang sakral sebagai realitas ilahi. Sesuatu yang hilang di Barat dalam kajian agama adalah suatu pengetahuan yang bisa memandang agama secara adil, yaitu dengan menggunakan perennial wisdom yang berada dalam "hati" semua tradisi-tradisi keagamaan. Philosophia perennis merupakan pengetahuan yang berada pada dalam "hati" agama yang bisa menerangkan makna ritus-ritus keagamaan, doktrin-doktrin dan simbol-simbol. Philosophia perennis juga menyediakan kunci untuk memahami pentingnya pluralitas agama dan metode untuk masuk kepada dunia agama lain tanpa mereduksi signifikansi atau menghilangkan komitmen kita kepada dunia agama yang menjadi kajian kita. philosophia perennis akan mengkaji agama dari segala aspeknya; Tuhan dan manusia, wahyu dan seni yang sakral, simbol-simbol dan images, ritus-ritus dan hukum-hukum agama, mistisisme dan etika sosial, metafisika, kosmologi dan teologi.

Demi mensukseskan dialog antar agama ataupun antar iman tersebut, maka pemahaman terhadap agama-agama lain tidak hanya diperlukan oleh para elit agama, tetapi harus merambah kepada masyarakat lapisan terbawah atau masyarakat awam yang bergesekan secara langsung dengan para pemeluk agama-agama lain dalam kehidupan sehari-hari.

Ilmu perbandingan agama dan pemahaman terhadap agama orang lain merupakan prasyarat untuk melakukan dialog antaragama, karena tanpa ini dialog mustahil dilaksanakan dan memang ilmu perbandingan agama dipergunakan untuk memperlancar dialog ini dan dialog antar agama sendiri merupakan media untuk memahami agama lain secara benar dan komprehensif.

Dialog antarumat beragama yang benar dapat menimbulkan pemahaman dan pencerahan kepada umat dalam wadah kerukunan hidup antarumat beragama27. Dalam dialog ini diperlukan sikap saling terbuka antarpemeluk agama yang berdialog. Sebenarnya menganggap bahwa agama yang dipeluk itu adalah agama yang paling benar bukanlah anggapan yang salah, bahkan yakin bahwa agama yang ia peluk adalah agama yang paling benar, dan orang lainpun dipersilahkan untuk meyakini bahwa agama yang ia peluk adalah agama yang paling benar. Malapetaka akan timbul apabila orang yang yakin bahwa agama yang ia peluk adalah agama yang paling benar, lalu beranggapan bahwa karena itu orang lain harus ikut ia untuk memeluk agama yang ia peluk.28

25 Hans Kung, "Sebuah Model Dialog Kristen-Islam" dalam Jurnal Paramadina (Jakarta, Paramadina Juli-Desember, 1998), 32.

26 Hossein Nasr, The Need of Sacred Science (United Kingdom: Curzon Press, 1993).

27 Mathews, World Religion (Canada: International Thompson Publishing, 1999), 432-433.

28 Mukti Ali, Ilmu Perbandingan Agama (Bandung: Mizan, 1998), 67-68. 
Menurut Azyumardi Azra,29ada beberapa model dialog antarumat beragama (tripologi), yaitu: Pertama, dialog parlementer (parliamentary dialogue), yakni dialog yang melibatkan ratusan peserta, seperti dialog World's Parliament of Religions pada tahun 1873 di Chicago, dan dialog-dialog yang pernah diselenggarakan oleh World Conference on Religion and Peace (WCRP) pada dekade 1980-an dan 1990-an. Kedua, dialog kelembagaan (Institutional Dialogue), yakni dialog diantara wakil-wakil institusional berbagai organisasi agama. Dialog kelembagaan ini sering dilakukan untuk membicarakan masalah-masalah mendesak yang dihadapi umat beragama yang berbeda. Dialog seperti ini biasanya melibatkan majelis-majelis agama yang diakui pemerintah seperti Majelis Ulama Indonesia (MUI), Persatuan Gereja Indonesia (PGI), Konferensi Waligereja Indonesia (KWI), Parisada Hindu Darmadan Perwalian Umat Budha Indonesia(WALUBI). Ketiga, dialog teologi (theological dialogue). Dialog ini mencakup pertemuan-pertemuan reguler maupun tidak, untuk membahas persoalan-persoalan teologis dan filosofis. Dialog teologi pada umumnya diselenggarakan kalangan intelektual atau organisasi-organisasi yang dibentuk untuk mengembangkan dialog antaragama, seperti interfidei, paramadina, LKiS, LP3M, MADIA, dan lain-lain. Keempat, dialog dalam masyarakat (dialogue in community), dialog kehidupan (dialogue of live), dialog seperti ini pada umumnya berkonsentrasi pada penyelesaian "hal-hal praktis dan aktual" dalam kehidupan yang menjadi perhatian bersama dan berbangsa dan bernegara. Dialog dalam kategori ini biasanya diselenggarakan kelompok-kelompok kajian dan LSM atau NGO. Kelima, dialog kerohanian (spritual dialogue), yaitu dialog yang bertujuan untuk menyuburkan dan memperdalam kehidupan spritual di antara berbagai agama.

Pada pihak Kristen, menurut Kate Zebiri30 sikap keterbukaan terhadap agama lain telah melahirkan gerakan antar iman yang pada dekade terakhir terekspresikan dalam dialog yang terorganisir. Vatican telah mendirikan sekretariat bagi agama non-Kristen (Pasific Council for Interreligious Dialogue-PCID) pada tahun 1964 yang mempunyai misi mempromosikan kajian tradisitradisi agama lain dan mensponsori dialog antar iman (interfaith dialogue). Vatican II (1962-5) juga telah mengeluarkan dokumen yang berisi tentang penghormatannya terhadap orang-orang muslim, karena mereka menyembah Satu Tuhan Yang Maha Hidup, Abadi, Pengasih dan Perkasa. Mereka juga tunduk sepenuh hatinya kepada takdir Tuhan, sebagaimana yang dilakukan Ibrahim yang merupakan sandaran keimanan Islam. Walaupun mereka tidak mengakui bahwa Yesus sebagai Tuhan tetapi mereka mengakuinya sebagai Nabi. Mereka juga menghormati Maryam, Ibu Yesus yang suci. Mereka juga menantikan Hari Perhitungan.

29 Azyumardi Azra, Konteks Berteologi di Indonesia: Pengalaman Islam (Jakarta: Paramadina, 1999), 63-64.

30 Kate Zebiri, Muslims and Christians, Face to Face (Oxford: Oneworld, 1997), 34-36. 
Praksis dialog agama yang sebenarnya seperti diungkap oleh Ahmad Gaus31 adalah, dialog yang meleburkan diri pada realitas dan tatanan sosial yang tidak adil dengan sikap kritis. Karena setiap agama memiliki nilai-nilai kebaikan dan misi penegakan moralitas.

Dengan tegas dikatakan oleh Mudji Sutrisno32, bahwa tidak cukup membangun dialog antaragama hanya dengan dialog-dialog logika rasional, namun perlu pula logika psikis. Maka ikhtiar dialog teologi kerukunan juga harus dibarengi dengan pencairan-pencairan psikologis, seperti rasa saling curiga yang selama ini selalu muncul. Memang, seperti juga yang diungkap oleh Kautsar Azhari33, bahwa kendala dialog antar umat beragama adalah persoalan eksklusivisme. Seorang eksklusivis akan terus berusaha agar orang lain mengikuti agamanya dengan menganggap agama orang lain keliru dan tidak selamat (truth claim).

Dengan demikian, sepanjang sikap di atas belum tercairkan, maka dialog menuju cita-cita agama yang luhur sulit dicapai. Maka jangan khawatir dengan dialog, karena yang ingin dicapai dalam dialog, kata Victor I. Tanja34 bukan soal kompromi akidah, melainkan bagaimana akhlak keagamaan kita dapat disumbangkan kepada orang lain. Dan seperti tegas Shihab35, bahwa kita tidak ingin mengatasnamakan ajaran agama, dan kemudian mengorbankan kerukunan beragama. Dan pada saat yang sama, kita tidak ingin menegakkan kerukunan agama dengan mengorbankan agama. Islam mendambakan kerukunan, tetapi jangan lantas demi kerukunan, agama kita terlecehkan.

Ulil Abshar Abdalla dalam artikelnya, "Beberapa Kendala Praktis Dialog Antar Agama”,36 menengarai tujuh kendala praktis di lapangan yang menghalangi pertemuan antar umat beragama, yaitu: adanya kecenderungan dialog yang bersifat diskursif dan elitis; kurang serius (baca: agresif) dalam memperjuangkan isu dialog; adanya kesenjangan antara kelompok elit agama dengan mediator ( $\left.d a^{\prime} i\right)$ di lapangan; tidak memadainya "infra struktur dialog"; adanya prasangka antar umat beragama dan juga intern umat beragama; adanya kesenjangan sosial dan ketidakadilan dan tidak adanya dialog intern umat beragama. Sementara menurut mantan menteri agama, Tholchah Hasan37, pembinaan kerukunan umat beragama yang ada selama ini, ditengarai masih cenderung berorientasi struktural dan politis.

Dalam melakukan dialog dengan agama lain, apapun bentuknya, diperlukan adanya sikap saling terbuka, saling menghormati dan kesediaan untuk mendengarkan yang lain38. Sikap-sikap ini diperlukan untuk mencari titik temu (kalimatun sawa') antara berbagai agama, karena masing-masing agama mempunyai karakteristik yang unik dan komplek. Huston Smith, dalam pengantarnya

31 Andito (ed.), Atas Nama Agama: Wacana Agama dalam Dialog "Bebas" Konflik, (Bandung: Pustaka Hidayah, 1998), 161-162.

32 Ibid., 335

33 Ibid.

34 Ibid

35 Ibid

36 Kompas $(5 / 8,2000)$.

37 Tolhah Hasan, Reaktualisasi Pembinaan Kerukunan Umat Beragama (Makalah Seminar, 1999).

38 Kate Zebiri, Muslims and Christians, Face to Face (Oxford: Oneworld, 1997). 
mengungkapkan tentang tesis Schuon mengenai hubungan antara agama-agama bahwa segala sesuatu memiliki persamaan dan sekaligus perbedaan, demikian juga dengan agama. Agama-agama yang hidup di dunia ini disebut "agama" karena masing-masing memiliki persamaan.

Persamaan atau titik temu antara agama-agama tersebut berada pada level esoterisme, sedangkan pada level eksoterieme, agama-agama tampak berbeda39. Oleh karena itu, untuk mencari titik temu antar agama, perlu adanya kajian esoteris terhadap agama. Menurut Raimundo Panikkar, untuk memahami agama-agama orang lain secara komprehensif, kita harus memahami agamanya (kitab agama) melalui bahasa aslinya. Kita tidak bisa mengabaikan perbedaan-perbedaan yang ada dalam masing-masing agama untuk menarik kesimpulan bahwa "semua harus menjadi satu". Menurutnya, setiap agama merefleksikan, membenarkan, menambahi dan melawan yang lain 40 .

\section{Pluralisme dan Dialog Antarumat Beragama}

\section{Beberapa Pendekatan:}

Harus diakui, bahwa agama-agama, disamping memiliki klaim absolutisme, juga memiliki klaim inklusivisme. Dalam konteks ini ada kasus menarik yang pernah dialami oleh Nabi Muhammad, yaitu ketika kaum musyrik bersikeras menolak ajaran Islam, maka demi kemaslahatan bersama Tuhan memerintahkan kepada Nabi untuk berkata kepada mereka: “....Tuhan kelak akan menghimpun kita semua, kemudian Dia memberi keputusan diantara kita dengan benar. Sesungguhnya Dia Maha Pemberi Keputusan lagi Maha Mengetahui”.41

Menurut penafsiran Quraish Shihab42 ketika absolutisitas diantar ke luar (ke dunia nyata), Nabi tidak diperintahkan untuk menyatakan apa yang ada di dalam (keyakinan tentang absolutisitas agama tersebut), tetapi justru sebaliknya. Itulah sebabnya menurut Quraish Shihab, bahwa salah satu kelemahan manusia adalah semangatnya yang menggebu-gebu, sehingga ada di antara mereka yang bersikap melebihi Tuhan, misalnya menginginkan agar seluruh manusia satu pendapat, menjadi satu aliran dan satu agama. Semangat yang menggebu-gebu ini pulalah yang mengantarkan mereka memaksakan pandangan absolutnya untuk dianut orang lain.

Pada umumnya kebanyakan filosuf berpendapat bahwa hakikat realitas tertinggi adalah satu, maka secara otomatis prinsip-prinsip filosofis yang digunakan semua agama juga satu. Ketika 'allamah Thabathaba'i berbicara tentang agama pada level filosofis ia tidak pernah bersikap permissif, tetapi ketika kajiannya mulai menyentuh dataran sosiologis ia sangat toleran, begitu pula muridnya, Muthahhari. Itulah sebabnya menurut Shahab, dalam masalah perbandingan agama hendaknya digunakan perspektif filosufis, bukan sosiologis, untuk menghindari pada jebakan simbolsimbol agama.

39 Schuon, The transcendent Unity of Religions. Wheston (Illinois: The Theosophical Publishing, 1984). 40 Pannikar, Dialog Intra Religius (Yogyakarta: Kanisius, 1994),

41 Perhatikan QS. 34:24-26.

42 Quraish Shihab, Membumikan al-Qur'an, (Bandung: Mizan, 1992), hlm. 222. 
Dalam menghadapi pluralisme agama, John Hick43 menawarkan pendekatan lintas budaya (crooss-cultural). Pendekatan ini menegaskan bahwa ada satu Tuhan tak terbatas (Maha Kuasa) yang ada di balik semua kesan dan pandangan agama yang berbeda. Oleh sebab itu menurut Hick, tidak beralasan bagi suatu agama yang mengklaim dirinya paling benar dan menganggap agama yang lain salah. Adalah tidak mungkin bahwa kesan paling lengkap atau kurang lengkap tentang Tuhan dilakukan dalam tradisi keagamaan yang berbeda. Dalam karyanya, On Grading Religions, Hick berusaha menilai agama-agama itu sebagai tradisi-tradisi yang utuh, (total) ketimbang melihatnya sebagai fenomena keagamaan yang partikular dan pada akhirnya merupakan kerja yang tidak realistik. Hick melihat tradisi perbedaan keagamaan dianggap sebagai sama-sama produktif (equallyproductive) dalam mengubah manusia dari perhatian pada diri sendiri (Self-Centredness) menuju perhatian pada Tuhan (Reality-Centredness). Hick dalam hal ini menganalisis kriteria dan pendekatanpendekatan evauluatif yang mungkin dapat membantu dalam menilai kultur keagamaan secara lengkap dan utuh.

Hick menganalisis tiga kriteria ketika orang menyambut dan menerima perantara Tuhan dalam membangun sebuah tradisi keagamaan. Pertama, adalah kriteria moral yang didasarkan pada sebuah tatanan moral universal, yang mempertanyakan: Apakah perantara (mediator) itu lebih baik dari kejahatan, dan apakah ajarannya menawarkan sebuah visi moral lebih baik dari pada moralitas umum yang ada? Kedua, kriteria yang menfokuskan pada kemampuan mediator untuk mengungkapkan visi baru tentang realitas yang mendorong manusia untuk mengikutinya: Apakah visi baru itu lebih baik, dan apakah kehidupan baru dan lebih baik itu bisa melalui mediator tersebut? Ketiga, kriteria yang memusatkan pada respon manusia: Apakah manusia bisa berubah dan dijamin bahwa Tuhan kenyataannya mengantarkan mereka?

Hick mengajukan evaluasi rasional mengenai kognisi, elemen-elemen teori mengenai tradisi keagamaan dan evaluasi moral tentang aktualisasi kultur-sejarah kepercayaan keagamaan. Namun menurut penilaian Stenger44 keduanya (baik evaluasi rasional maupun moral) mengarah pada kesimpulan positif dan negatif, lebih kuat dan lebih lemah yang memberi contoh setiap tradisi. Orang boleh juga mempertanyakan, apakah visi dasar keagamaan berlanjut menjadi efektif secara "soteriologic" (soteriologically effective) atau hidup yang transformatif, tetapi akhir pembuktian tentang itu menurut Stenger bersifat eskatologis.

Memang, sebagaimana penilaian Stenger, Hick tidak menemukan kriteria yang cukup untuk perbandingan yang memadai dan penilaian yang baik terhadap tradisi keagamaan secara utuh. Meski begitu menurut Stenger, kriteria-kriteria yang dibuat Hick itu bisa dipakai pada fenomena keagamaan

43 Thomas Dean, ed. Religious Pluralism and Truth Essays on Cross-Cultural Philosophy of Religion. (State University of New York, 1985), 92; Hick, John Problem of Religious Pluralism (London: The Macmillan Press, 1985), 53.

44 Lihat Tracy, Plurality and Ambiguity, Hermeneutic, Religion, Hope (University of Chicago Press), 1987), 90.

45 Ibid., 93. 
khusus dan oleh karena itu patut dipertimbangkan dalam persolan yang terkait dengan isu penilaian kebenaran keagamaan tersebut.

Hick mengatakan bahwa semua cara yang ditempuh agama-agama menuntut transformasi tunggal mengenai diri: dari pemusatan diri (Self-Centredness) menuju pemusatan Tuhan (RealityCentredness). Dalam beberapa cara keagamaan, orang harus merubah perhatian ego dengan menggunakan hubungan baru dengan Tuhan. Hanya kemudian, dapatkah diri (self) berhenti menjadi ego dan menemukan kebebasan otentik yang dihubungkan dengan alam, sejarah, dan yang lain? Adalah tidak mungkin bahwa semua pencerahan keagamaan berbeda ekspresi dari posisi keagamaan yang sama. Pluralitas diantara agama-agama tidaklah mereduksi terhadap klaim bahwa mereka semua memperlihatkan pencerahan yang sama atau praktik yang sama tentang kebebasan 45 .

Brian Fay46 dalam mengkaji fenomena sosial menggunakan pendekatan yang disebut dengan pendekatan multikultural. Ada dua belas pendekatan multikultural dalam filsafat ilmu sosial yang dibangun oleh Fay. Pendekatan ini mencoba mendamaikan berbagai perbedaan pandangan dalam ilmu sosial dengan cara yang lebih mendalam, plural, inklusif, tanpa sekat dan subjektivisme.

Dalam filsafat ilmu sosial terdapat pola yang bersifat dualistis yang mendominasi. Pola itu terkait dengan pertanyaan: "Apakah satu pilihan atau pilihan lainnya-dan kemudian salah satu diantaranya dianggap pilihan yang benar?" Fay berusaha menghindari dualisme yang merusak, misalnya: diri vs. orang lain; subjetivisme vs. objektivisme; atomisme vs. holisme; kebudayaan kita vs. kebudayaan mereka; orang dalam vs. orang luar; kesamaan vs. perbedaan dst.

Fay menjelaskan tentang "memahami orang lain" dan "mengkritik orang lain". Antara memahami dan mengkritik adalah dua hal yang berbeda. Ilmu sosial terkait dengan usaha memahami orang lain bukannya menilai orang lain.

Dari dua belas tesis filsafat multikultural yang dibangun Fay ini, ada empat poin yang penulis anggap tepat untuk memahami pluralisme agama, yaitu: pertama, mewaspadai adanya dikotomi, menghindari dualisme buruk dan berpikir secara dialektis. Sebagaimana yang disarankan oleh Fay, kita tidak boleh terjebak pada kategori-kategori yang saling bertolak belakang. Kategori-kategori atau dikotomi-dikotomi itu harus disikapi secara terbuka dan dipikirkan secara dialektis; kedua, tidak menganggap orang lain sebagai "yang lain”. Sebenaranya semua identitas pribadi pada hakikatnya menurut Fay bersifat dialogis. Tidak ada pemahaman diri tanpa pemahaman orang lain, dan jangkauan kesadaran diri kita dibatasi oleh pengetahuan orang lain; ketiga, mentransendensikan kesalahan memilih antara universalisme dan partikularisme, asimilasi dan pemisahan. Hendaknya kita memanfaatkan perbedaan, dengan mengambil hikmah, pembelajaran dan saling menguntungkan; keempat, berpikir secara proses, dengan pengertian kata kerja bukan kata benda (produk). Jika umat beragama mampu menggunakan pendekatan multikultural dalam berinteraksi, maka keberadaan

46 Brian Fay, Contemporary Philosophy of Social Science (Oxford: Blackwell Publisher, 1996). 
agama dan perbedaan yang ada diantara agama-agama tidak akan menimbulkan pertentangan dan konflik yang membahayakan.

Menyangkut masalah pemahaman dan peran agama, secara umum, dapat dilihat dari dua aspek. Pertama adalah aspek konatif (conative aspects). Aspek ini berkaitan dengan kemampuan agama dalam menyediakan sarana kepada masyarakat dan anggota-anggotanya untuk membantu mereka menyelesaikan berbagai persoalan kehidupan. Kedua, aspeknya yang bersifat kognitif (cognitive aspects). Aspek ini terkait dengan peranan agama dalam menetapkan kerangka makna yang dipakai oleh manusia dalam menafsirkan secara moral berbagai kesukaran dan keberhasilan pribadi mereka; juga sejarah masyarakat mereka di masa yang silam dan keadaannya di masa kini,47

Pemahaman terhadap peranan agama semacam itu dapat ditemukan batu pijakannya dalam berbagai sumber suci agama-agama semit. Dalam Islam misalnya, al-Quran tidak hanya mewajibkan kepada umatnya untuk melakukan ibadah-ibadah ritual-seremonial yang bisa memberikan kelegaan emosional dan spiritual, tetapi juga membuka ruang penafsiran intelektual guna membantu manusia dalam mendapatkan makna dari seluruh pengalaman hidupnya. Peranan Islam seperti ini tampak dengan jelas dalam hampir setiap ibadah ritualnya selalu terkandung apa yang biasa disebut dengan pesan moral. Bahkan begitu pentingnya pesan moral ini, "harga" suatu ibadah dalam Islam dinilai dari sejauh mana pesan moralnya bisa dijalankan oleh manusianya. Apabila suatu ibadah tidak bisa meningkatkan moral seseorang, maka ibadahnya dianggap tidak ada maknanya. Oleh karena itu, ketika seseorang melakukan hal-hal yang terlarang secara fiqh dalam suatu ibadah, maka tebusannya adalah menjalankan pesan moral itu sendiri. Misalnya, pada bulan puasa, sepasang suami istri berhubungan intim pada siang hari, maka kifarat (dendanya) ialah memberi makan enam puluh orang miskin, karena salah satu pesan moral puasa ialah memperhatikan orang-orang yang lapar di sekitarnya.

Aspek kognitif peranan agama semacam ini juga bisa dijumpai dalam agama Kristen. Narasi tentang Ayub dalam Bibel misalnya — atau Nabi Ayyub dalam al-Quran—merupakan simbol persoalan kemanusiaan yang mengandung ajaran moral sangat dalam. Kesungguhan Ayub dalam menjalankan kewajiban sosial dan keagamaan memang tidak serta merta menjadikannya bahagia, sebaliknya menyebabkan dia memperoleh cobaan penderitaan. Tetapi kesungguhan Ayub dalam menghayati niali-nilai sakral yang terdapat dalam perintah-perintah Tuhan bukan hanya menyebabkan dia bertahan atas penderitaan tersebut, namun juga membantu dia menemukan makna dari seluruh pengalaman hidupnya. Sehingga, ketika Ayub minta keterangan kepada Tuhan tentang apa yang terjadi, bukan keadaan dirinya yang diutamakan tetapi justru nasib buruk yang menimpa seluruh umatnya yang dikedepankan. 48

47 Elizabeth K.Notingham, Agama dan Masyarakat. Terjemahan A. Muis Naharong (Jakarta: Rajawali Press, 1985), 107-109.

48 Ibid. 
Pesan agama yang terpantul dari kisah tentang Ayub itu adalah, bahwa ketidaksamaan nasib untung dan malang manusia tidak dapat dijelaskan begitu saja menurut ukuran baik buruk manusiawi, tetapi harus dilihat pula dari segi adanya penilaian-penilaian Tuhan di dalamnya. Di situlah terletak (salah satu) fungsi agama yang penting, yaitu "memberikan makna moral dalam pengalamanpengalaman kemanusiaan". Makna moral di sini paralel dengan apa yang dikatakan oleh Paul B. Horton dan Chester L. Hunt49, bahwa semua agama besar menekankan kebajikan seperti kejujuran dan cinta sesama. Kebajikan seperti ini sangat penting bagi keteraturan perilaku masyarakat manusia, dan agama membantu manusia untuk memandang serius kebajikan seperti itu.

Persoalan makna agama sebagaimana tergambar pada ajaran Islam dan Kristen di atas merupakan persoalan makna agama dalam pengalaman individual. Secara esensial, persoalan yang sama bisa juga ditemukan pada level masyarakat secara keseluruhannya. Persoalan-persoalan seperti ketidakadilan sosial, kesenjangan ekonomi, serta persoalan kekuasaan merupakan rahasia umum dalam kehidupan masyarakat manusia. Fenomena semacam ini secara sosiologis sangat bisa mendorong timbulnya penafsiran-penafsiran moral terhadap tertib sosial yang ada. Pada situasi dan kondisi tertentu tidak jarang dapat menimbulkan konflik-konflik sosial, apabila interpretasi yang dilakukan oleh masing-masing anggota masyarakat tidak mencapai titik temunya.

Atas dasar pemahaman seperti itu, persoalan makna agama dalam pengalaman masyarakat menjadi lebih unik dan rumit dibanding pada pengalaman individu. Apabila suatu masyarakat mampu memahami peranan agama dalam membantu menafsirkan secara moral pengalaman hidupnya secara tepat, maka agama akan hadir sebagaimana fungsinya. Sebaliknya, jika mereka salah dalam melakukan interpretasi-interpretasi tersebut maka agama bisa menjadi lahan subur bagi perkembangan konflik di tengah-tengah masyarakat.

Jika agama memang menyumbang perdamaian, maka penganut agama harus belajar meninggalkan absolutisme dan menerima pluralisme, demikian ungkap Nurcholish Madjid.50 Kita boleh memandang agama sebagai absolut, namun yang harus diingat bahwa pemahaman kita --baik pribadi maupun kelompok-- menyimpan kualitas kemanusiaan yang relatif. Petunjuk konkret untuk memupuk persaudaraan menurut Nurcholish adalah, supaya suatu kelompok dari kalangan orangorang beriman tidak memandang rendah atau meremehkan orang dan agama lain.

Sekurang-kurangnya menurut Bambang Sugiharto51, tantangan yang dihadapi setiap agama saat ini ada tiga: pertama, soal disintegrasi dan degradasi moral; kedua, soal pluralisme dan eksklusivisme; ketiga, soal ketidakadilan. Ketiga persoalan tersebut sulit diatasi karena beberapa faktor, di antaranya adalah: karena adanya sikap agresif yang berlebihan terhadap pemeluk agama lain; adanya konsep kemutlakan Tuhan yang disalahmengertikan; dan adanya kepentingan luar agama

49 Chester L. Hunt, 1993, 304.

50 Andito (ed.), Atas Nama Agama: Wacana Agama dalam Dialog “Bebas” Konflik (Bandung: Pustaka Hidayah, 1998), 161-162.

51 Ibid., 29-32. 
(politik, ekonomi) yang turut mengintervensi agama. Tetapi jika faktor di atas dapat diselesaikan, maka tantangan-tantangan tersebut juga dapat dijawab.

Menurut Armahedi Azhar, terdapat lima penyakit yang menghinggapi para aktivis gerakan keagamaan, yaitu: absolutisme, ekslusivisme, fanatisme, ekstremisme dan agresivisme. Absolutisme adalah kesombongan intelektual, ekslusivisme adalah kesombongan sosial, fanatisme adalah kesombongan emosional, ekstremisme adalah sikap yang berlebihan dan agresivisme adalah tindakan fisik yang berlebihan.52

Dalam kaitannya dengan pluralisme agama di Indonesia, Victor I. Tanja53 menganjurkan adanya reorientasi misi dan dakwah. Menurut Tanja, tujuan misi dan dakwah bukan untuk menambah jumlah kuantitas, melainkan harus dilandaskan pada menciptakan umat yang tinggi ilmu, tinggi iman dan tinggi pengabdian (kualitas umat). Sejalan dengan Tanja, Shahab menegaskan bahwa ketegangan agama yang terjadi selama ini adalah karena pelaku dakwah ( $d a^{\prime} i$, muballigh, missionaris) adalah orang-orang yang cinta pada agamanya, tetapi tidak memiliki pengetahuan agama secara mendalam. Akibatnya dakwahnya lebih cenderung propagandis dan provokatif.

Tentu saja dengan masih adanya konflik antar umat pada beberapa tahun terakhir ini tidak bisa dikembalikan begitu saja kesalahannya pada pendekatan dialog secara an sich sebab disamping ada faktor-faktor lain yang ikut ambil bagian di dalamnya seperti ekonomi, hukum, politik dan seterusnya. Sudah saatnya kini para pemuka agama mulai mengedepankan misi agama yang terkait dengan masalah spiritualitas dan persoalan kemanusiaan (keadilan, kejujuran, dan keramahan). Oleh sebab itu, salah satu hal yang perlu diperhatikan dalam rangka menciptakan kerukunan umat beragama di tengah pluralitas ini adalah dengan memahami ajaran agama masing-masing secara utuh.

\section{KESIMPULAN}

Pluralisme merupakan kenyataan sejarah yang tidak bisa diingkari keberadaannya, dan merupakan tantangan yang dihadapi oleh agama-agama dunia dewasa ini. Untuk menghadapi tantangan pluralisme, diperlukan pemahaman yang plural terhadap agama. Setiap agama hendaknya dinilai sebagai tradisi-tradisi yang utuh, bukan sebagai fenomena keagamaan yang partikular. Tradisi perbedaan keagamaan hendaknya dianggap sebagai sama-sama produktif (equally-productive) dalam mengubah manusia dari perhatian pada diri sendiri (Self-Centredness) menuju perhatian pada Tuhan (Reality-Centredness).

Semua agama cenderung memiliki klaim absolutisme, baik Islam, Kristen Hindu maupun Yahudi. Klaim pemeluk agama monoteisme yang partikularistk-subjektif akan berdampak pada konflik antarumat beragama, dan konflik tersebut akan menjadi memuncak jika beberapa organisasi keagamaan yang kuat dan partikularistik hidup berdampingan.

52 Ibid. 15.

53 Ibid., 79. 
Tidak ada agama yang memiliki esensi tunggal. Yang ada adalah perbedaan penafsiran tentang Tuhan: God, Emptiness, Suchness, the One, Nature, the Many. Perbedaan agama-agama hanya berada pada level eksoterisme, sementara pada level esoterisme terdapat titik temu. Kita tidak bisa mengabaikan perbedaan-perbedaan yang ada dalam masing-masing agama untuk menarik kesimpulan bahwa "semua harus menjadi satu".

Dalam memahami persoalan agama-agama perlu pendekatan multikultural, dimana pendekatan ini berusaha menjauhkan sikap absolut, subjektif dan ekslusif. Pemahaman ini juga setara dengan pendekatan yang digunakan oleh Schuon dengan istilah esoterisme, atau yang digunakan Hick dengan pendekatan cross-cultural-nya dan Nasr dengan philosophia-perennia-nya. Mengedepankan aspek moral dan sosial dalam agama juga diperlukan agar agama tampil sebagai pembawa rahmat bagi semesta alam. Wallahu a'lam bi-al-Sawab.

\section{DAFTAR PUSTAKA}

Abu Rabi', Ibrahim. "Christian-Muslim Relations in Indonesia: The Challenges of The Twenty-First Century" Jurnal Studia Islamika. Jakarta: IAIN Syarif Hidayatullah, 1998.

Ali, Mukti H. A.. Ilmu Perbandingan Agama di Indonesia, Bandung: Mizan, 1998.

Andito (ed.). Atas Nama Agama: Wacana Agama dalam Dialog “Bebas” Konflik, Bandung: Pustaka Hidayah, 1998.

Arikunto, S. Prosedur Penelitian: Suatu Pendekatan Praktis, Jakarta: Bina Aksara,1989.

Ary D. et.al.. Introduction to Research in Education, The Third Education, New York: Holt, Rinehart and Wiston, 1985.

Azra, Azyumardi.. Konteks Berteologi di Indonesia: Pengalaman Islam, Jakarta: Paramadina, 1999.

Coward, Harold.. Pluralisme dan Tantangan Agama-Agama, Yogyakarta: Kanisius, 1989.

Dean, Thomas, ed. Religious Pluralism and Truth Essays on Cross-Cultural Philosophy of Religion. State University of New York, 1985.

Depag RI. Al-Qur'an dan Terjemahannya, Jakarta: Depag RI. 1995.

Dian Interfidei. Dialog: Kritik dan Identitas Agama, seri Dian I Th. I,. 1995.

Fay, Brian Contemporary Philosophy of Social Science. Oxford: Blackwell Publisher. 1996.

Geerz, Cliffort. Abangan, Santri, Priyayi Dalam Masyarakat Jawa, Jakarta, Surya Grafindo, 1985.

Hanafi, Hassan. 1977. Religious Dialogue \& Revolution, Essay on Judaism, Christianity \& Islam, Cairo: The Anglo Egyptian Bookshop. 
Hasan, Thalchah.. Reaktualisasi Pembinaan Kerukunan Umat Beragama, makalah tidak diterbitkan. 1999

Hick, John Problem of Religious Pluralism. London: The Macmillan Press, 1985.

Hornby, AS. Oxford Advanced Learner's Dictionary of Current English, Oxford: University Press. 1986.

Jurnal Ulumul Qur'an.1993. No. 4, Volume IV.

Kompas, 2000/ 05/ 08.

Kung, Hans. "Sebuah Model Dialog Kristen-Islam" dalam Jurnal Paramadina, Jakarta, Paramadina Juli-Desember, 1998.

Lyden, John (Editor). Enduring Issues in Religion, San Diego: Greenhaven Press. 1995.

Mahfuz, Abdul Ghoffar. Tokoh Agama dalam Mewujudkan Kerukunan Antarumat Beragama (Studi Kasus di Kec. Bukit Intan Kodya Pangkal Pinang), Palembang, Puslit IAIN Raden Fatah. 1997.

Mastudu dan M. Deden Ridwan (eds.)..Tradisi Baru Penelitian Agama Islam: Tinjauan Antar Disiplin Ilmu, Jakarta, Pusjarlit. 2000

Mathews, Warren.World Religion, Canada: International Thompson Publishing, 1999.

Nasr, Seyyed Hossein. The Need for Sacred Science, United Kingdom: Curzon Press, 1993.

Notingham, Elizabeth K. Agama dan Masyarakat. Terjemahan A. Muis Naharong, Jakarta: Rajawali Press, 1985.

Puspito, Hendro, OC. Sosiologi Agama, Yogyakarta: Kanisius, 1984.

Qowa'id. "Dialog Antarumat Beragama di Kalimantan Selatan”, Jakarta, Jurnal Penamas No. 39, Th. XIV. 2001.

Ropi, Ismatu. Fragile Relation: Muslims and Christians in Modern Indonesia Jakarta: Logos. 2000.

Schuon, Frithjof The transcendent Unity of Religions. Wheston, Illinois: The Theosophical Publishing House, 1984.

Shihab, Quraish, Membumikan al-Qur'an, Bandung: Mizan, 1992.

Soroush, Abdul Karim Menggugat Otoritas dan Tradisi Agama, terjemahan Abdullah Ali, Bandung: Mizan, 2003.

Stark, Rodney. One True God: Resiko Sejarah Bertuhan Satu, penerjemah M. Sadat Ismail, Jakarta, Nizam, Yogyakarta: Qalam, 2003. 
Sudarta. Konflik Islam-Kristen, Menguak Akar Masalah Hubungan Antar umat Beragama di Indonesia, Semarang: Pustaka Rizki Putra, 1999.

Sumarthana, T.H. "Menuju Dialog Antar Iman”, Pengantar dalam Dialog : Kritik dan Identitas Agama, Yogyakarta: Dian/Interfedei, Seri Dian I/Tahun I. 1993.

Suparlan P. "Kebudayaan, Masyarakat dan Agama: Agama Sebagai Sasaran Penelitian Antropologi” dalam Parsudi Suparlan (ed), Pengetahuan Budaya, Ilmu-Ilmu Sosial dan Pengkajian Masalah-Masalah Agama, Jakarta, Badan Litbang Agama, Departemen Agama RI. 1982.

Suparlan P. Manusia, Kebudayaan dan Lingkungannya. Jakarta, Rajawali Press, 1984.

Suparlan P. "Agama Sebagai Sasaran dan Penelitian" dalam Sujangi (ed), Kajian Agama dan Masyarakat, Jakarta, Badan Litbang Departemen Agama RI. 1991.

Tracy, David. Plurality and Ambiguity, Hermeneutic, Religion, Hope. University of Chicago Press, 1987.

Yahya, M., et.al. Respon Masyarakat Awam (Islam-Kristen) Terhadap Dialog Antarumat Beragama di Kabupaten Malang, Laporan Hasil Penelitian Hibah Bersaing Depag RI. 2002.

Zakiyuddin. Ambivelensi Agama, Konflik dan Nirkekerasan. Yogyakarta: Lesfi, 2002.

Zebiri, Kate. Muslims and Christians, Face to Face, Oxford: Oneworld, 1997.

Zulaikha, Siti. "Toleransi Awu-awu: Potret Dialog Antar Agama di Jawa Timur" Surabaya: Jurnal Gerbang, Oktober-Januari, 2002-2003.

Zainuddin, M. Potret Kerukunan Hidup Antarumat Beragama di Malang Selatan, Jakarta: Mediacita, 2002 